Elena Parina

Institute of Linguistics

Russian Academy of Sciences

Moscow, Russia

\title{
LOANWORDS IN WELSH: \\ FREQUENCY ANALYSIS ON THE BASIS OF CRONFA ELECTRONEG O GYMRAEG ${ }^{1}$
}

\section{Introduction}

During their long history Welsh people have contacted many other nations and therefore adopted a multitude of borrowings into their language. The main source languages for Welsh were Latin, Norman French and English, to which we should add the influx of Irish, Hebrew and Greek words, and to a small extent those of the Scandinavian languages. These source languages are regarded from unequal points of view by both speakers and scholars. Whereas Latin and Norman French, Irish, Hebrew and Greek loanwords are considered noble in a way, English loanwords are very often seen as marking a degraded stage of the Welsh language. As noted by Prof. Hildegard L. C. Tristram, issues of English influence on the Insular Celtic languages have not received due attention because of political undercurrents in the British Isles - this is regarded as an issue of the influence of the colonialists' language on the language of the so-called "internal English colonies" (Tristram 2002: 258).

This difference is reflected in the uneven distribution of the academic scholarship dedicated to various source languages. Latin borrowings are the best studied ones - their study began in the 1870s in the works of John Rhys (1873-74; 1885), among others, was continued by Henry Lewis (1943) and summed up by Haarmann (1970). Latin loanwords in Old Welsh received special attention in a very detailed paper by Alexander Falileyev (2002). Works on English borrowings are fewer in number, though they started at roughly the same time with publications by Ellis (1882), and Powel

${ }^{1}$ Ellis, N. C., O’Dochartaigh, C., Hicks, W., Morgan, M., \& Laporte, N. (2001). Cronfa Electroneg o Gymraeg (CEG): A 1 million word lexical database and frequency count for Welsh. [http://www.bangor.ac.uk/ar/cb/ceg.php.en ] 
(1882-1884). The major work on the subject still remains "The English element in Welsh: a study of English loan-words in Welsh" by T. H. ParryWilliams (1923). In the 1940s Robert Fowkes described in a series of articles in the journal Word various aspects of English influence on the Welsh language and noted that his subject of research induced negative reaction in the speakers (Fowkes 1945; 1948; 1949; 1954). ${ }^{2}$ Highly valuable data is contained in the works of dialectologists, which cannot be prescriptive by definition. Thus Alan Thomas writes in his Introduction to the "Linguistic Atlas of Wales":

A comment on the relevance of the notion "loan-word" to the purpose of this investigation may be appropriate. Attempts to distinguish "well-established" loans from "recent" loans in historical terms, or to assess the currency and usage of loan-forms relative to that of an indigenous Welsh word with which they might be associated, would take us beyond the geographical aims of the investigation. Responses are accepted or rejected on the basis of their distribution-patterns alone. It is assumed that any "loan" which is consistently attested within a restricted area is representative of the vernacular of that area, and there is no discussion or characterisation of "loan"-words as entities which are distinct from "regional" words (LGW 7-8).

However, the prevailing attitude of the past few years is indicated by an article title such as "Sut i beidio ag ysgrifennu Saesneg yn Gymraeg" (How not to write English in Welsh) published in the journal Mabon in 1970s (Roberts 1973). A notable exception to this tendency is a work by Dr. Clive Gray "The English Element of Welsh" (Grey 2008), which was almost unavailable outside of Wales until recently. Nowadays there are interesting projects on bilingualism and code-switching conducted at the University of Wales in Bangor, which again are fact-describing and not prescriptive. But still many questions require further investigation.

\section{The methodology of the study}

This study should begin with an unbiased evaluation of the loanwords' presence in a given period of time. There are several possible ways to examine this. One is to estimate the number of borrowings in the Swadesh 100 list of the most stable words, which is used in glottochronology. We have complet-

\footnotetext{
${ }^{2}$ Suffice it to say that Fowkes was an American scholar, which may serve as a good illustration to the suggestion expressed by Prof. Tristram, who pointed out that the study of English influence on the Welsh language was considered to be politically incorrect in the British Isles.
} 
ed this at the previous Celto-Slavica conference (Parina 2006). There are four English loanwords in this list, which did not completely displace the Welsh words. These can be compared to seven Latin borrowings, most of which probably displaced the British words already in the period before the common British language divided into Breton, Cornish and Welsh (see Parina 2006, Parina 2009.). Another way to estimate the presence of loanwords is to estimate their frequency. One possible method is to estimate the number of loanwords in the 1000 most frequent words in a reliable corpus of texts. This can be easily done, as the 1,000,000-word Welsh Bangor corpus provides a frequency list of all the words. Words in this list should not be treated as vocabulary entries because different grammatical forms are considered as different words. However, forms with different initial mutations are counted as one.

\section{Source language: Latin}

We first turn to the classical subject of Latin loanwords. Among the 1000 most frequent words there are 87 Latin borrowings and 40 English borrowings. We present them with the first figure indicating the number of entries in the corpus, followed by GPC's suggestion of the word's etymology (at the current stage of our research we follow the opinion proposed by this authority) and the time of its first written occurrence: ${ }^{3}$

1. pobl 'people'- 1440 (+ pobol-193) - GPC 2836: L. poplus < populus (12$13 \mathrm{c.})$

2. plant 'children'-1047 - GPC 2818: L. planta (9-10 c.)

3. ysgol 'school'- 979 - GPC 3839: L. schola (13 c.)

4. addysg 'education'- 720 - GPC 35: L. addisco (14 c.)

5. modd 'mode'- 646 - GPC 2473: L. modus (13 c.)

6. nifer 'number, host'- 633 - GPC 2582: L. numerus (9 c.)

7. canol 'middle'- 607 - GPC 414: L. canālis 'pipe, gutter' (14 c.)

8. dysgu 'teach, learn'- 604 - GPC 1148: L. disco (c. 1200)

9. prif 'main'- 597 - GPC 2886: L. prīmus (12-13 c.)

10. cynnwys 'content'- 596 - GPC 788: L. condenso (13 c.)

11. eglwys 'church'- 594 - GPC 1177: Late L. ec(c)lesia (12 c.)

12. llyfr 'book'- 472 - GPC 2255: L. libr(um) (12-13 c.)

${ }^{3}$ As is well known most of the manuscripts in Welsh, which survived until our days, date from the $13 \mathrm{c}$., before that the number and volume of written sources is much more scarce. Therefore the date of the first occurrence in a manuscript does by no means coincide with the date of the borrowing, though it might be significant in case of later loanwords. 
13. achos 'cause'-424-GPC 8: L. occāsio, 'semantics affected by similar words cāsus, causa' (c. 1200)

14. Saesneg 'English language'- 425 - GPC 3158: L. Saxonica (lingua) (13 c.)

15. diwrnod 'day'-414 - GPC 1060: L. diurnāta (c. 1200)

16. ysgolion - $\mathrm{pl}-$ ysgol 412

17. symud 'move'- 404 - GPC 3388: L. summūt(ō), summōtus (13 c.)

18. coleg 'college'- 382 - GPC 543: Late L. collegium (1604)

19. parod 'ready'- 377 - GPC 2691: L. parātus (13 c.)

20. llyfrau-pl - llyfr 375

21. cynnig 'offer'- 368 - GPC 791: L. condico (c. 1200)

22. sôn 'talk, rumour'- 357 - GPC 3319: L. sonus (12-13 c.)

23. capel 'chapel'-345 - GPC 420: Late L. cappella (c. 1300)

24. aml 'often'- 339 - GPC 94: L. amplus (13 c.)

25. creu 'create'- 337 - GPC 584: L. creo (c. 1200)

26. profiad 'experience'- 329 - GPC 2903: from prof-af < L. prob-ō (verb $-12-13$ c., noun- 15 c.)

27. corff 'body'-324 - GPC 550: L. corpus (c. 1200)

28. ystyried 'consider'- 296 - GPC 3870: v. ystyr (12 c.)

29. disgyblion 'students'- 293 - GPC 1046: Late L. discip'lus (13 c.)

30. plentyn -sg - plant 272

31. coch 'red'- 262 - GPC 525: Late L. coccum (12 c.)

32. ystafell 'room'-261 - GPC 3860: L. " stabellum <stabulum (9-10 c.)

33. syniad 'idea'- 239 - GPC 3392: from syni-af (< L. sent-iō)+-iad (verb -12 c., noun $-14 \mathrm{c}$.)

34. awdurdod 'authority'-236 - GPC 239: L. au(c)tōritāt-em (12 c.)

35. awr 'hour'-227 - GPC 242: L. hōra (10 c.)

36. ysgrifennu 'write'- 226 - GPC 3844: from ysgrifen 'writing' $<\mathrm{L}$. scrībendum (noun $-9 \mathrm{c}$., verb - $13 \mathrm{c}$.)

37. munud 'minute'- 225 - GPC 2502: Late L. minūtum, minūta, probably through French or English (14 c.)

38. ffurf'form'-224 - GPC 1325: L. fōrma (13 c.)

39. llong 'ship'- 221 - GPC 2204: L. (navis) longa (12 c.)

40. cylch 'circle'- 219 - GPC 747: L. circ'lus < circulus = OW. $\operatorname{circhl}(10$ c.)

41. mawrth 'March'- 203 - GPC 2386: L. (mensis) Mārtius (13 c.) mawrth 'Tuesday'- - GPC 2386: L. (dies) Mārtis (13 c.)

42. Iesu 'Jesus'- 203 L. Iesu 
43. pur 'pure'- 201 - GPC 2930: L. pūrus (13 c.)

44. llythyr 'letter'- 190 - GPC 2284: L. littera(e) (9 c.)

45. cyson 'constant'-189 - GPC 815: L. consonus (12-13 c.)

46. ysbryd 'spirit'- 188 - GPC 3825: L. spīitus > spiritus (12-13 c.)

47. testun 'text'-188 - GPC 3489: L. testimōnium (c. 1400)

48. eglwysi-pl -eglwys 187

49. prifysgol 'university'- 185 -cf. prif + ysgol (1604-1607)

50. awdur 'author'-185 - GPC 239: L. au(c)tōr-em (13 c.)

51. diffyg 'defect'-183 - GPC 993: Spoken L. dĩficium (9 c.)

52. ystyr 'meaning'- 182 - GPC 3870: L. historia (12 c.)

53. priodol 'proper, appropriate' < 172 - GPC 2896 priod 'proper' (14-15 c.)

54. esgob 'bishop'- 172 - GPC 1243: L. episcopus (12 c.)

55. effeithiol 'effective'- 172 - GPC 1174: from effaith < L. effectus + iol (adj. - 1587, noun - 1584)

56. mesur 'measure'- 169 - GPC 2440: Br. L. mesūra< mēnsūra (9 c.)

57. awdurdodau - $\mathrm{pl}$ - см. awdurdod 169

58. sail 'base'- 168 - GPC 3169: Spoken L. *solia< solea (12 c.)

59. pwysau pl. - pwys 165

60. ffydd 'faith'- 164 - GPC 1331: L. fides (12-13 c.)

61. milltir 'mile'- 163 - GPC 2460: ? mil 'thousand' + tir 'land'(13 c.)

62. ysgrifennydd 'secretary'- 159 - GPC 3845 cf. ysgrifennu (13 c.)

63. nadolig 'Christmas'- 156 - GPC 2547: Spoken L. Natālicia (13 c.)

64. cadair 'chair'- 155 - GPC 375: L. cathedra (12-13 c.)

65. anifeiliaid 'animals'- 155 - GPC 131: Late scholar L. anĭmălium (c. 1200)

66. cymuned 'community' - 150 cymuned 'community' - GPC records only cymuniad 'Communion'< L. communio (GPC 772). In the Welsh Academy English-Welsh dictionary community is translated with cyffredinrwydd, Eccl. cymundod, cymdeithas - the word cymuned is given far from beginning of the entry with a note "in sociological jargon" (GA 274). In the German-Welsh / Welsh-German dictionary, which is much more usage-oriented the cymuned word has a number of meanings and illustrated with several examples: Gemeinschaft, Gemeinde; $Y$ Gymuned Ewropeaidd - die Europäische Gemeinschaft ... (GAC 673)

67. elfen 'element'- 149 - GPC 1205: L. elementum (1567)

68. graddau pl. 'degree'- 146 - GPC 1518: L. gradus (13 c.)

69. ysbyty 'hospital'- 142 - GPC 3828: esbyd < L. hospites + ty 'house' (13 c.) 
70. Ewrop 'Europe'- 139 - L. Europa

71. addysgol 'educational'- 137 - GPC 35: cf. addysg (1722)

72. poblogaeth 'population'- 136 - GPC 2837: poblog (< pobl + og $)+$ aeth cf. pobol (1780)

73. llongau -pl - llong 135

74. cadeirydd 'chairman'- 135 - GPC 377: cadair + ydd, cм. cadair (1827)

75. hwyr 'late'- 134 - GPC 1942: possibly from L. sērus, but can be a Br. word (13 c.)

76. pregethu 'preach'- 133 - GPC 2871: from pregeth 'sermon'< L. preccettum/preccetta < præceptum/præcepta (verb and noun - 13 c.)

77. ffenestr 'window'- 132 - GPC 1282: L. fenestra (13 c.)

78. dibynnu 'depend'- 131 - GPC 957: L. dependeo (13 c.)

79. nod 'note, mark, target'- 131 - GPC 2587: L. nota (13 c.)

80. pwys 'pound'- 130 - GPC 2953: L. * pēsum < pēnsum (13 c.)

81. plwyf 'parish'-129 - GPC 2830: L. plēb- (13 c.)

82. astudio 'learn, study'- 127 - GPC 223: from astud 'diligent' < L. astūtus (14-15 c.)

83. ffurfio 'to form'- 126 - GPC 1326: cf. ffurf(13 c.)

84. hwyrach 'later'- hwyr 126

85. myfyrwyr 'students'- 125 - GPC 2529 from myfyr-io 'study, meditate' (< myfyr 'meditation' - - GPC 2527: L. memoria (13 c.)) +iwr (15 c.)

86. mil 'thousand'- 125 - GPC 2455: L. mïlia (13 c.)

87. syml 'simple'-125 - GPC 3386: L. simplus (13 c.)

We compared this list with the one in an almost classical work by Harald Haarmann, where he divides Latin loanwords in twenty Sachgruppen following Franz Dornseiff (1970). The following groups contain the largest number of loanwords from the top 1000 frequency list: Thought (including Education) (11 words), Society (11), Religion (8). This is a good illustration of the well-known fact that even after the withdrawal of the Roman troops, Latin was the language of religion and education in Britain as well in Western Europe in general. It is in these groups that we find words absent from the work of $\mathrm{H}$. Haarmann, that is prifysgol 'university', coleg 'college' and capel 'chapel'. The word munud 'minute' is not there either, but the exact source language for this word is disputed in GPC.

This question of the way a certain Latin word came into the language is very important for our study. At this stage we followed GPC, therefore words like 
412 stori - GPC 3339 E. story pl. ystorïau, storis (15 c.)

233 person-GPC 2778: M.E. or AN. person(e) (13 c.)

147 cwricwlwm - GPC 648: E. curriculum from L. (20 c.)

are not in the first, but in the second list. Nevertheless they all are doubtless L. words originally.

3. Source language: English

The list of English loanwords contains 40 words.

1. ffordd 'road, way' - 987 - GPC 1304: O.E. ford (12 c.)

2. cwrs - 611 - GPC 648: M.E. course (1346)

3. stori - 412 - GPC 3339 E. story pl. ystoriau, storis (15 c.)

4. sir - 385 - GPC 3291 M.E. shire (14 c.)

5. bwrdd 'board, table'- 273 - GPC 355: O.E. bord (12-13 c.)

6. sicr - 266 - GPC 3268: M.E. siker 'safe, sure' (15 c.)

7. posibl - 249 - GPC 2860: E. possible (15 c.)

8. person - 233 - GPC 2778: M.E. or O.Fr. person(e) (13 c.)

9. rheswm - 223 - GPC 3060: M.E. res(o)un (15 c.)

10. mater - 213 - GPC 2347: E. matter (15-16 c.)

11. drama - 209 - GPC 1025: E. drama (1825)

12. cwestiwn - 200 - GPC 636: M.E. questioun, cwestiun (15 c.)

13. clir - 186 - GPC 500: E. clear (16 c.)

14. presennol-184-GPC 2877: presen, $-t-$ L. ${ }^{*}$ present-< præsent- $:+o l-$ (14 c.)

15. polisi - 184 - GPC 2846: E. policy (1900)

16. teledu 'television' - 181 - GPC 3472: *tel (cf. E. television + (darll) edu) $(20$ c.)

17. personol - 180 - GPC 2779 person + ol (1401)

18. nofel - 177 - GPC 2594: E. novel (1771)

19. ffwrdd - 176 - GPC 1330: < ffordd (1567)

20. te - 175 - GPC 3459: E. tea (1722)

21. proses - 171 - GPC 2910: O.Fr. proces, possibly through M.E.

process- 1896 ; b) narration, story, discourse (14 c.); c) legal process (15 c.)

22. problem - 166 - GPC 2900: E. problem (1888)

23. staff - 163 - GPC 3326: E. staff (1916)

24. siop - 159 - GPC 3289: M.E. shop(p)e or from French of England or O.Fr. (14 c.) 
25. syr - 158 - GPC 3396: M.E. sir(e) or O.Fr. sire (14 c.)

26. patrwm - 158 - GPC 2702: M.E. patroun 'pattern' (15-16c.)

27. fferm - 154 - GPC 1284: M.E. ferm(e) (15 c.)

28. efel-148 - GPC 2057: E. level (1621)

29. busnes - 148 - GPC 349: E. business (16 c.)

30. cwricwlwm - 147 - GPC 648: E. curriculum from L. (20 c.)

31. $c l w b-147$ - GPC 512: E. club (18 c.)

32. problemau - 146 - problem

33. posib - 145 - GPC 2860: posib (18 c.)

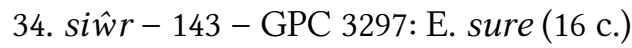

35. criw - 143 - GPC 601 E. crew (16 c.)

36. materion - 138 - GPC 2347: E. matter (15-16 c.)

37. pwrpas - 137 - GPC 2944: E.Mod.W. purpas (1547)

38. ffilm - 135 - GPC 1288: E. film (19 в)

39. ffyrdd - 132 - GPC gw. ffordd

40. sgwrs - 125 - GPC 3255: from disgwrs < E. discourse (19 c.)

Most of these loanwords are rather old and already occur in the $16 \mathrm{c}$.. The many recent ones denote new realities. We leave aside a detailed semantic classification of these words in this work, as in the system used by H. Haarmann (Dornseiff's Sachgruppen). Most of the words actually appear in several Sachgruppen, so that it is not a convenient tool for sorting our loanwords.

Comparison with the frequency list of the British National corpus however provides some semantic information. We use here the version given in [Leech, Rayson, Wilson 2001]. Such a comparison is impeded by several obstacles, the major ones being polysemy of the Welsh word and different syntax - i.e. different use of singular-plural forms in case of nouns, different use of tense forms in case of verbs etc. Therefore what follows are only some preliminary remarks. Almost $70 \%$ of loanwords from English have quite the same frequencies as their English counterparts. The Latin list is somewhat different - on the one hand the high frequency of words like awdurdodau and cymuned is likely to be dictated by English discourse, being analogues of fashionable words of the late 20 c. On the other hand in this list only $43 \%$ of Welsh words included occur in the corpus with the same frequency as their main English equivalent. 53\% (47 words out of 88 ) occur significantly more often. $21.5 \%$ of them (19 words) are included to the Dornseiff's Sachgruppen "Thought/ education" and "Religion". This does not only testify to the importance 
of Latin in those fields, but also to the importance of religious writing in the bulk of Welsh literature, which is reflected in the Bangor Welsh corpus.

\begin{tabular}{|l|l|l|l|}
\hline & frequency & & frequency per 1000000 words \\
\hline ysgol & 979 & school & 375 \\
\hline addysg & 720 & education & 260 \\
\hline dysgu & 604 & $\begin{array}{l}\text { teach } \\
\text { learn }\end{array}$ & $\begin{array}{l}\text { teaching 57, teach 28 } \\
\text { learning 38, learn 83 }\end{array}$ \\
\hline eglwys & 594 & church & 203 \\
\hline llyfr & 472 & book & 243 \\
\hline ysgolion & 412 & schools & 154 \\
\hline coleg & 382 & college & 102 \\
\hline llyfrau & 375 & books & 131 \\
\hline capel & 345 & chapel & 20 \\
\hline disgyblion & 293 & pupils & 81 \\
\hline ysgrifennu & 226 & write & write 109 \\
writes 26 writing 63
\end{tabular}

The word preach does not appear in the BNC at all, while words like chapel, spirit and faith are not represented among the top 1000 lists of the British National Corpus. Thus we deduce from this loanword study not only conclusions on the role which Latin and English play in the formation of the Welsh vocabulary, but also on the nature of the Corpus itself. 


\section{Conclusion}

In conclusion we would like to draw attention to the fact that the issue of loanwords in Welsh, esp. of English loanwords, is not a purely academic one. At the beginning of our paper we mentioned that certain cultural and political undercurrents have played their role in the past in making such research unpopular. This negative attitude is of vital importance for the future of the Welsh language. A huge gap still exists between the literary norm and spoken dialects in Welsh. On the lexical level one of the most obvious differences is the wide use of loanwords in spoken language and a tendency to avoid them in the literary standard. This purism can be, as David Crystal, a famous sociolinguist, writes in his article "Is Welsh safe?", a question of life and death for a minority language (Crystal 1998). Many Welshmen grow up with the sense of not being able to speak "proper Welsh", so in a public, formal situation they immediately switch to English, which reduces the use of the Welsh language. Therefore we believe that an acceptance of the diversity of Welsh vocabulary as a whole, including loanwords, by both scholars and speakers would help to ensure the future of this Celtic language.

Abbreviations

GA: see Griffiths \& Jones 1995.

GAC: see Greller 1999.

GPC: Geiriadur Prifysgol Cymru, 1950-2002, Caerdydd.

LGW: see Thomas 1973.

LHEB: see Jackson 1953.

References

CRYSTAL, D., 1998: Is Welsh safe? (www.crystalreference.com/DC_articles/ Langdeath11.pdf, downloaded 7.09.2007)

DoRnSEIFF, FR., 1970: Der deutsche Wortschatz nach Sachgruppen, Berlin-NY ( $7^{\text {th }}$ edition).

Ellis, AleXANDer J., 1882: 'On the Delimitation of the English and Welsh Language', in: Cymmrodor 5, 173-208.

Falileyev, A. I., 2002: 'Latin Loanwords in Old Welsh (A Chapter on Historical Lexicology of Welsh)' (In Russian: 'Латинские заимствования в 
древневаллийском (Глава из исторической лексикологии валлийского языка)'), in: Colloquia classica et indo-evropeica III, Saint-Petersburg, 347-366.

Fowkes, R. A., 1945: 'English Idiom in Modern Welsh', in: Word 1, 239-48.

FowKes, R. A., 1948: 'Prosody in the Influence of English on Welsh', in: Word 4, 37-41.

FowKes, R. A., 1949: 'Initial Mutation of Loanwords in Welsh', in: Word 5, 20513.

FowKes, R. A., 1954: 'On the Gender of Early English Loanwords in Welsh', in: Word 10, 66-70.

GRELLER, W., ED., 1999: Geiriadur Almaeneg-Cymraeg, Cymraeg-Almaeneg/ Wörterbuch Deutsch-Walisisch, Walisisch-Deutsch, Aberystwyth.

GREY, C., 2008: The English Element of Welsh, Working draft.

GrifFiths, B., \& Jones, D. G., EDS., 1995: Welsh Academy English-Welsh Dictionary: Geiriadur Yr Academi, Cardiff.

HaARmann, H., 1970: Der lateinische Lehnwortschatz im Kymrischen, Bonn.

JACKSON, K., 1953: Language and History in Early Britain, Edinburgh.

LeEch, G., Rayson, P., Wilson, A., 2001: Word Frequencies in Written and Spoken English: Based on the British National Corpus, London. (partly available at: http://ucrel.lancs.ac.uk/bncfreq/flists.html)

LewIs, H., 1943: Yr elfen Ladin yn yr iaith Gymraeg, Caerdydd.

Lотн, J., 1892: Les mots latins dans les langues brittoniques, Paris.

MüHLHAUSEN, L., 1914: 'Die lateinischen, romanischen, germanischen Lehnwörter des Cymrischen, besonders im 'Codex Venedotianus' der cymrischen Gesetze', in: FS Ernst Windisch, Leipzig, 249-348.

Parina, E., 2006: 'Modern Welsh Word List for Glottochronology' (In Russian: 'Стословный список лексики валлийского языка для глоттохронологии'), in: Second International Colloquium of Societas Celto-Slavica, Abstracts, Moscow, 73.

Parina, E., 2008: 'Latin Loanwords in Modern Welsh' (In Russian, 'Латинские заимствования в современном валлийском языке'), in: Colloquia Classica et Indo-evropeica, 12, Saint-Petersburg, 364-370.

PARINA, E., 2009: '100-Word List of Basic Lexis for Modern Welsh' (In Russian: 'Стословный список базовой лексики для современного валлийского языка'), in: Mikhailova, T., Mac Mathúna, S., Fomin, M., \& Bondarenko, G., Proceedings of the Second International Colloquium of Societas CeltoSlavica, Studia Celto-Slavica 2, Moscow: MGU Publishers,

ParRY-Williams, T. H., 1923: The English element in Welsh: a study of English loan-words in Welsh, London.

Powel, Тн., 1882-84: 'The Treatment of English Borrowed Words in Colloquial Welsh', in: TPS, 355-78. 
RHYs, J., 1873-1874: 'Welsh Words Borrowed from Latin, Greek and Hebrew', in: Archaeologia Cambrensis, $4^{\text {th }}$ series, 4-5.

RHYs, J., 1875: 'Welsh Words Borrowed from the Classical Languages', in: Archaeologia Cambrensis, $4^{\text {th }}$ series, 6.

Roberts, E., 1973: 'Sut i beidio ag ysgrifennu Saesneg yn Gymraeg', in: $M a-$ bon.

Thomas, A. R., 1973: The Linguistic Geography of Wales, Cardiff.

Tristram, H., 2002: 'The Politics of Language: Links between Modern Welsh and English', in: Of dyuersitie \& chaunge of langage. Essays Presented to Manfred Görlach on the Occasion of his $65^{\text {th }}$ Birthday, Heidelberg, 257-76.

\title{
Posuđenice u velškome: Čestotna analiza na osnovi Cronfa Electroneg o Gymraeg
}

\begin{abstract}
Sažetak
Velški je posuđivao riječi iz nekoliko jezika, od kojih su najznačajniji latinski, normanski francuski i engleski. Mišljenje ljudi koji govore velški o tom pitanju vidi se iz niza članaka koji su izlazili u časopisu Mabon u 70-ima: Sut i beidio ag ysgrifennu Saesneg yn Gymraeg (Kako ne pisati engleski u velškom). Ovaj preskriptivizam izbjegava se većinom u dijalektalnim i u istraživanjima promjene kôda koja a priori ne mogu biti preskriptivna. Ipak, mnogi problemi još nisu opisani. U ovom radu iznose se rezultati istraživanja posuđenica u dva velška korpusa. Prvi bi točnije bilo nazvati zbirka tekstova, budući da je samo dio dostupan u elektroničkom obliku. Sastoji se od jedanaest tekstova Mabinogija u širem smislu (Gost Lady Charlotte) i predstavlja klasičan primjer srednjovelškog proznog jezika. Drugi je korpus Bangor, korpus novovelškog jezika. Izdvajajući posuđenice u 1000 najčešćih riječi u oba korpusa i uspoređujući ta dva niza dobiva se omjer engleskih i latinskih posuđenica, njihovo mjesto u cijelom rječniku i međusobni odnos srednjo- i novovelškog. Posuđenice niže čestote pomažu da se dobiju točniji rezultati.
\end{abstract}

Ključne riječi: velški, srednjovelški, latinski, posuđenice, korpus

Key words: Welsh, Middle Welsh, Latin, loanwords, corpus 